\title{
THE EFFECT OF SCAFFOLDING-BASED PROBLEM-BASED LEARNING APPROACHES TO IMPROVE MATHEMATICAL MODELING ABILITY OF ELEMENTARY SCHOOL STUDENTS
}

\author{
Ariyanti ${ }^{1}$ dan Neni Hermita ${ }^{2}$ \\ ${ }^{1}$ Dinas Pendidikan KCD Wilayah VII, Jawa Barat, INDONESIA \\ 2Universitas Riau, Riau, INDONESIA
}

Received 07 Pebruary 2020 - Revised 29 February 2020 - Accepted 29 March 2020

\begin{abstract}
This study aims to examine the improvement of mathematical modeling skills by using a problem-based learning approach based on scaffolding in elementary school students and to see the effect of the interaction between the learning approaches applied (PBL-based scaffolding and conventional) and the students' initial mathematical ability to improve mathematical modeling abilities. This research was conducted in 3 elementary schools located in the city of Bandung with the number of research subject classes consisting of 2 classes namely the experimental class and the control class. Experimental class getting learning with problem based learning approach based on scaffolding and control class getting conventional learning. The research design uses Quasi-Experimental design with pre-posttest design. The results showed that the increase in mathematical modeling skills in students who were given learning with PBL based on scaffolding was higher than students who were taught conventionally and there was an influence of interaction between the learning approaches applied (PBL based on scaffolding and conventional) and the students' initial mathematical ability towards increasing ability mathematical modeling.
\end{abstract}

Keywords: problem based learning based on scaffolding, modeling capabilities mathematical, elementary school

\section{INTRODUCTION}

Construction in learning mathematics can be done based on the results of analysis of students' mastery of concepts and mathematical skills. The number of mathematical concepts (for example: numbers, equations, numbers, etc.) and accompanied by various mathematical processes (for example: the process of solving linear equations) is an unavoidable condition in the process of learning mathematics because mathematical concepts and procedures are used as strong "tools" in solving problems. The consequence is that the mathematical situation in the construction of mathematics learning is needed so that there is a deep understanding of a student in the process of mastering mathematical concepts as well as an understanding of the procedures that

(C) 2019 by the authors; licensee PGSD UMP. This article is an open access article distributed under the terms and conditions of the Creative Commons Attribution License (http://creativecommons.org/licenses/by/4.0/). $\checkmark$ aryantiba28@gmail.com (*Correspondence) $\square$ neni.hermita@lecturer.unri.ac.id 
accompany these concepts. The process of creating this mathematical situation must be through identification that is valid enough to provide conditions that really give space to students to be able to develop their abilities. This process can be identified in various ways, one of which is stated by Schifter, Russell, and Bastable (1999) who say that "Some mathematical understandings ... can be identified through "listening to students, recognizing common areas of confusion, and analyzing issues that underlie that confusion". The results of this thought provide strong information that in the process of learning mathematics does not always run in accordance with the expected goals, but often found various problems or "difficulties" experienced by students and can be identified through a process of identifying difficulties by listening to students and recognizing and analyzing concepts concepts that make students "confused" in learning mathematics. Through this identification ideas can be obtained to provide the development of a deep understanding of mathematics so students do not see mathematics as an idea that is interrupted between concepts, skills and facts, but views mathematics as a coherent set of ideas. (Randall \& Carmell, 2005).

The issue of difficulties experienced by students is not a new thing. Several studies have shown that mathematical difficulties always occur in students. Boaler $(1999 ; 2002)$ found that students often seemed unable to solve problems that required a combination of real-life knowledge with mathematical knowledge received at school, as well as failing to transfer formal mathematical knowledge to real-life problems. This serious situation is problematic and affects students' motivation to learn mathematics. Even specifically, Mousoulides, Christou, and Sriraman (2008) found one type of student difficulty, namely students failing to understand the core questions of the problem and they also did not successfully connect the core questions with the data provided. However, they have failed to deal with and relate this understanding to the core questions of the problem, and Crouch and Haines (2004) report that interphase between real world problems and mathematical models that present student difficulties, namely the transition from the real world to mathematical models and vice versa transition model solutions to the real world. Likewise (Maas, 2006) reports the form of errors that occur when students model problems, including the difficulty of students to create a relationship between reality and mathematics, and to simplify and structure reality, as well as problems related to mathematical solutions.

The difficulty of students in carrying out a mathematical modeling process is very apparent from the results achieved by students in a survey in the Program for International Student Assessment (PISA) in 2012 which placed Indonesian students ranked 64th out of 65 participating countries with a mean score for the mathematics field of 375 (OECD, 2014, p. 5). Apart from all the arguments given to the results of this survey, but this survey is focused on "mathematics, with reading, science and problem-solving" so that it describes a fairly comprehensive condition regarding mathematical skills that have been learned by students aged 15 years. The results of this survey reflect the fact that the ability of students to utilize their knowledge to solve problems is relatively low when compared to students from other countries. That is, through the focus in this PISA survey, a flow of thought can be drawn that students' ability to solve real-world problems into a mathematical model (mathematical modeling process) is still low. There is no denying that students involved in the survey 
are students who are in the Middle School (SMP) level, but if a straight line is drawn backward then it can be given an understanding that the mathematical abilities of students in junior high are currently related to mathematical abilities possessed as elementary school graduates especially the ability related to mathematical modeling as one of the important components in a problem solving process.

The problem of mathematical modeling at the elementary level is often debated by education experts about the urgency of the modeling context at the elementary level. But Greer, Verschaffel and Mukhopadhyay (2007) believe that modeling and its application can begin at the elementary school level. Verschaffel (2002) says that certain types of "story problems" are good enough exercises for mathematical modeling. This means that, the construction of mathematical modeling in elementary school becomes quite important to be mastered by a student in accordance with the level of depth of the problem and its characteristics.

In mathematical modeling, students develop mathematical processes such as describing, explaining, predicting, representing, and organizing data (NCTM, 2000). In the same book it was stated that mathematical modeling is a process of "mathematical representation" of concepts and relationships in a phenomenon that can be used to clarify understanding and be used to solve problems ". It was further stated that, the act of mathematical modeling does not only include representation, but "acts" on representations and interprets the meaning of one's actions in mathematical models and on the phenomena being modeled.

Some researchers have found conditions that form when a student engages in mathematical modeling activities, for example students must identify problem variables and their relationships and describe mathematical situations (Mousoulides, N .; Pittalis, M. \& Christou, C., 2006); students are fully involved in the mathematical modeling cycle by testing the initial model in a particular context, then revising and generalizing the model by placing it in a different context (English, 2003; Doerr \& English, 2003; Lesh \& Doerr, 2003). That the purpose of mathematical modeling can develop procedural and abstract skills with conceptual understanding as a result of the modeling process and student involvement with problems (English, 2003; Lesh \& Doerr, 2003; Lesh, Doerr, Post \& Zawojewski, 2003; Mousoulides, 2006). At the same time, students are challenged to develop their mathematical thinking, namely to explain, connect, change and generalize information, not just understand mathematical content or specific skills (Lesh \& Zawojewski, 2007; Swan, 2007) (quoted from Papageorgiou, 2009: 8). The conditions formed, directing students in a mathematical process such as quantifying, dimensioning, coordinating, categorizing, algebraizing, and systematizing relevant objects, relationships, actions, patterns, and regularities whose principle is a mathematical thought process. In addition, mathematical modeling also helps students to make an external understanding of the situation built by the model through the conceptualization of mathematical ideas and processes (Lesh \& Doerr, 2003).

The description emphasizes the importance of a student in developing mathematical modeling skills in the construction of his thinking. Mathematical modeling ability is very helpful in achieving the learning objectives of mathematics listed in Permendiknas No. 22 concerning Content Standards for Elementary and Secondary Education Units (BSNP, 2006), that students are able to (1) understand 
mathematical concepts, explain the interrelationships of concepts and apply concepts or algorithms, flexibly, accurately, efficiently and precisely in problem solving, (2) using reasoning on patterns and properties, through mathematical manipulation in making generalizations, compiling evidence, or explaining mathematical ideas and statements, (3) solving problems that include the ability to understand problems, design mathematical models, solve models and interpret the solutions obtained, (4) communicating ideas with symbols, tables, diagrams or other media to clarify the situation or problem, and (5) having an attitude of appreciating the usefulness of mathematics in life, namely having curiosity, attention and interest in learning mathematics, as well as being tenacious and confident in problem solving.

Mathematical programming is also very useful with the concept of learning mathematics in elementary school. Curran $(2013$, p. 3) refers to two core components of mathematics that must be discussed in elementary schools namely Standards for Mathematical Practice and Standards for Mathematical Content. The first type of thinking is learning mathematics which will produce learning lessons and help students in understanding mathematics according to their cognitive development and the second type is related to big concepts and skills that must be learned in each class. The mathematical modeling position is able to create a place that provides an opportunity for students to understand the two components above.

Another problem that can cause students to have difficulty understanding mathematical modeling and mathematical communication is the lack of student understanding of techniques and strategies for solving problems and students' mathematical thinking processes that are not yet critical and analytical. One effort to improve students' ability to do mathematical modeling is to improve mathematics learning models in the classroom; explain and apply techniques and problem solving models in mathematical modeling; and provide exercises towards developing students 'thinking power so that students' mathematical thinking is more critical and analytical.

Then, during the process of learning mathematics, the difficulties experienced by students, have been identified by Haylock \& Thangata $(2007$, p. 13) who have been able to identify that several things concerning the condition of a student in dealing with a mathematical assignment are: (a) students panic when confronted with mathematical assignments and unable to think clearly and remember things that are already known and able to be done, (b) Students have feelings of fear when dealing with mathematical assignments and excessive worry about getting wrong answers, (c) Students develop beliefs that they can not do this and even expect to get a bad assessment in mathematics, and (d) because there is a belief that they can not understand, students do the method of learning "memorization" by trying to memorize concepts, rules so that learning is not done understanding process.

The entire description above illustrates that the ability of elementary school students to do the mathematical modeling process is still low as indicated by the large number of students who experience difficulties and this has an impact on students' ability to solve problems. Mathematical modeling ability is a very important element in a problem solving process, so students who have difficulty in these two processes will almost certainly not be able to solve a mathematical problem. The ability to solve 
problems is also very necessary for humans because it relates to everyday life. According to Wahyudin $(2013$, p. 3) that problem solving is not just a skill to be taught and used in mathematics but is also a skill that will be brought to students' daily problems or decision-making situations, thus the ability of problem solving helps someone in his life.

The construction of the researchers' thought in providing this alternative solution is to realize that the implementation of learning so far, students often "sink" with their own busyness without any effort to arouse optimal abilities in students. Construction of learning that is more "teacher centered" has an impact on the difficulty of students in expressing mathematical ideas they have in the process of "mathematical modeling". The instructions given are very fixated on the examples in the textbooks, so students have difficulty in giving correct, clear, and logical explanations for the answers. Cai, Lane, Jakabcsin (1996) that as a result of very rarely students are required to provide explanations in mathematics, so it is very strange for them to talk about mathematics.

In general, students assume that mathematics is a difficult subject to understand so that not a few students are afraid of mathematics. With such conditions and also lack of enthusiasm students result in learning mathematics is often low. In addition, the teaching and learning process so far still uses teacher-centered learning systems (teacher centered) using the lecture method and the approach used is still textual, all of that must change and be followed by the teacher responsible for organizing learning in schools. One of the changes is the teacher centered learning orientation which is centered on the student (student centered), the methodology that was originally dominated by expository changes to participatory and the approach that was originally textual changed to contextual. All changes are intended to improve the quality of education, both in terms of process and education.

The description above, shows the existence of conditions that provide an overview of the "construction problems" that will be examined in this study. The description of these conditions provides an understanding of the difficulties students develop mathematical modeling and communication skills in a problem solving process. This assumption becomes important as a basis for researchers to construct the construction of problem solving by basing it on a process of selecting designs and strategies used in mathematics learning.

For this reason, mathematics learning is expected to be taught through strategies or methods capable of developing students' process skills in addition to mastering facts and procedures. Students are encouraged to be more active in learning in accordance with the interests, talents and development of students themselves. Mathematics is taught by using a variety of concrete and abstract representations which are adjusted to the stage of thinking of children because mathematics learning in elementary schools must be adapted to the characteristics of these students where media representations use more concrete objects and contextual and realistic situations.

Based on the description above, one solution that can be done is by applying the Scaffolding-based Problem based learning model. Research on problem based learning has indeed been done a lot, but on a certain side shows the existence of several researchers who question the effectiveness and efficiency of PBL. For example, responsibility and autonomy experienced by students can become unstructured, chaotic and even lead to stress (Sierens, Soenens, Vansteenkiste, Goossens, \& Dochy, 
2006). Kirschner, Sweller, and Clark (2006) argue that the PBL approach can cause ineffective cognitive resources that are already limited, and as such, are not optimally designed for learning. Furthermore, solving complex problems without prior knowledge of the solution procedure puts a high burden on memory. (Clark, Kirschner, \& Sweller, 2012; Kirschner et al., 2006; Sweller, Kirschner, \& Clark, 2007).

The above opinion directs researchers to carry out the PBL process through a limited guidance. Problem based learning is a learning model that uses real world problems as a context for students to learn critical thinking and problem solving skills, as well as to obtain essential knowledge and concepts from subject matter. According to Riyanto (2009, p. 288) states that Problem based learning focuses on students becoming independent learning and actively involved in group learning. This model helps students to develop students' thinking in finding solutions to problems through data searching in order to obtain solutions to a problem rationally and authentically.

According to Brunner scaffolding as a process in which a student is helped to solve certain problems beyond his development capacity through the help of a teacher or other people who have more abilities. As according to Kozulin and Presseisen (1995) (in Drajati, 2007) scafolding ie students are given complex tasks, difficult but systematic and then students are given assistance to complete them. Not the other way around, which is a learning system in parts, little by little or component by component of a complex task. Scaffolding is help, support for students from people who are more mature or more competent, especially teachers who allow the use of higher cognitive functions and enable the development of learning abilities so that there is a higher level of mastery of the material shown by the completion of the questions more complicated.

The above description provides an understanding that the provision of scaffolding is to provide assistance to students who are still and do not understand student material well to certain limits. Provision of scaffolding can be through the help of teachers and their peers. The context is how far the scaffolding is given will depend very much on the various variables that contribute to the scaffolding process. One of the variables is the basis for scaffolding students through continuous assessment or formative value-based.

Thus, the combination of problem based learning and scaffolding learning, hereinafter referred to as problem based learning Scaffolding based learning, provides essence as a learning model that uses real world problems as a context for students to learn critical thinking and problem solving skills, as well as to gain knowledge and concepts that are The essential of the subject matter is through the technique of providing learning support which in the initial stages is given in a more structured manner, then gradually leads students towards learning independence which aims to encourage students to become independent students. Considering the very importance of using Scaffolding-based Problem-based learning models in improving communication skills and mathematical modeling, the research focuses on the application of Scaffolding-Based Problem-based learning in developing communication skills and mathematical modeling of students. 


\section{MATERIAL AND METHODS}

\section{Methods}

This research was conducted in 3 elementary schools located in the city of Bandung which have school status with high, medium and low school status criteria. The basis for determining school status is the results of the UN Mathematics study field. The number of research subject classes consisted of 2 classes namely the experimental class and the control class so this study used 6 classes in 3 different elementary schools. The research design uses Quasi-Experimental design with pre-posttest design (Creswell, 2012). The use of this type is because the research will be planned as follows:

Time

\begin{tabular}{|c|c|c|c|}
\hline Control Group & Pretest & Non Treatment & Posttest \\
\hline $\begin{array}{c}\text { Experimental } \\
\text { Group }\end{array}$ & Pretest & $\begin{array}{c}\text { Experimental } \\
\text { Treatment }\end{array}$ & Posttest \\
\hline
\end{tabular}

Based on this type, the research applies the pre and post test design, which is divided into two research groups namely the control group and the experimental group. This type of research design is quantitative. In addition, the selection of this type of research is based on:

1. The type of data collected is quantitative data and will be analyzed using descriptive and inferential statistical analysis techniques.

2. The results of a literature review that presents the correlation between variables agreed upon through the formulation of hypotheses.

3. Accept clear limits on the variables to be discussed

Experimental class getting learning with problem based learning approach based on scaffolding and control class getting conventional learning. Classroom selection is done purposively, which emphasizes the context of the material and the characteristics of students for the mathematical modeling process. For this reason, the researcher chose grade $\mathrm{V}$ of elementary school in conducting this research. The number of subjects was 191 students with details: in the experimental class were 89 students and the control class were 102 students, each of whom was spread over 3 different elementary schools. The research instrument consisted of an observation sheet for the application of a scaffolding-based problem-based learning approach and a set of tests in the form of a pre-test and a post-test of mathematical modeling ability.

\section{Instrument}

The instrument was developed using the description form to measure the dependent variable in this study. This instrument validation was developed through the following stages:

1. Determine the scope of the material to be measured. This is done by defining the test lattice correctly and clearly.

2. This process is in the domain of instrument review from experts. Components for analyzing the realm of material, realm of construction, and the realm of language. Indicators from each domain are:

a. Language Domain: (1) Item questions according to indicators, (2) Limitation of expected questions and answers is clear, (3) The contents of the material are in 
accordance with the measurement objectives, (4) The contents of the material asked are in accordance with the level, type of school, and grade level.

b. Domains of Construction: (1) Formulation of sentences in the form of question or question sentences that require answers to be decomposed, (2) There are clear instructions on how to work / solve problems, (3) There are guidelines for scoring, (4) Tables, graphs, diagrams, cases, or the like is meaningful (clearly related or related to the problem being asked), (5) Item does not depend on the previous item.

c. Domain Language: (1) Comunicative sentence formulation. Sentences use good and correct language, and according to the variety of languages, (2) Formulation of sentences does not cause double interpretation or misunderstanding, (3) Using common language / words (not local language), (4) Formulation of questions does not contain words words that can offend students. (Directorate of Secondary General Education, 2003).

3. The test is corrected and the trial is carried out again.

4. The test is then declared worthy of use.

The post-test that was compiled by the researcher received a review from an expert to obtain construct validation in accordance with the competencies being taught. The results of this improvement were then tested in another school, namely SD Angkasa 2 involving 89 students in grade $\mathrm{V}$.

The results of the trial are presented in the following Table 1.

Table 1. Validity of each item in the post-test instrument

\begin{tabular}{|c|l|c|c|c|}
\hline No & Description & $\begin{array}{c}\text { Correlation } \\
\text { Value }\end{array}$ & Sign. & Decision \\
\hline 1 & Correlation between item 1 and total score & 0,536 & 0,000 & Valid \\
\hline 2 & Correlation between item 2 and total score & 0,691 & 0,000 & Valid \\
\hline 3 & Correlation between item 3 and total score & 0,566 & 0,000 & Valid \\
\hline 4 & Correlation between item 4 and total score & 0,726 & 0,000 & Valid \\
\hline 5 & Correlation between item 5 and total score & 0,706 & 0,000 & Valid \\
\hline \multicolumn{4}{|c|}{ All items in the instrument declared valid } \\
\hline
\end{tabular}

Then the test results with the Cronbach Alpha Coefficient Test model show that the Cronbach alpha value of 0.653 . This value is greater than the recommended Cronbach alpha value $\geq 0.60$ for exploratory research and $\geq 0.70$ for confirmatory research (Latan, 2014). This means that this instrument meets the recommended requirements and is suitable for this research. The total statistical items are presented in the following Table 2.

Table 2. Total statistical items in the reliability test of the post-test instruments

Item-Total Statistics

\begin{tabular}{|r|r|r|r|r|}
\hline & $\begin{array}{c}\text { Scale Mean if } \\
\text { Item Deleted }\end{array}$ & $\begin{array}{c}\text { Scale Variance if } \\
\text { Item Deleted }\end{array}$ & $\begin{array}{c}\text { Corrected Item- } \\
\text { Total } \\
\text { Correlation }\end{array}$ & $\begin{array}{c}\text { Cronbach's } \\
\text { Alpha if Item } \\
\text { Deleted }\end{array}$ \\
\hline Item 1 & 3,6742 & 6,109 &, 311 &, 641 \\
Item 2 & 2,9775 & 4,818 &, 401 &, 611 \\
Item 3 & 3,8876 & 6,010 &, 353 &, 625 \\
Item 4 & 3,2809 & 4,841 &, 493 &, 556 \\
Item 5 & 3,7528 & 5,143 &, 494 &, 559 \\
\hline
\end{tabular}




\section{Procedures}

This research procedure is a series of activities that will be carried out in carrying out research. The steps are as follows:

1. Determine the subject population and sample subjects.

2. Making research instruments for each variable and subject matter taught.

3. Analyzing the results of trials by examining elements of instrument validity, instrument reliability.

4. Randomly selecting the experimental group and the control group.

5. Carry out learning with a problem based learning approach based on scaffolding.

6. Carry out posttest after each subject. The posttest question includes math modeling problems.

7. Analyze pretest and posttest data by:

a) makes a description of: (1) learning through problem based learning based on scaffolding, (2) Mathematical modeling ability.

b) test the normality and homogeneity of data on each variable studied. Data normality is seen from the Kolmogorov-Smirnov test results. Homogeneity seen and Levene test results.

c) test differences in the ability of mathematical modeling of research subjects in the experimental group and the control group. Testing uses two-way ANOVA.

8. Making a research report.

\section{Data Analysis}

Based on the data collected, the validity of the instrument will be tested based on the consideration of the promoter team and the magnitude of the reliability coefficient calculated by the Product Moment formula from Pearson and Cochran's Q Test. The type of data collected is quantitative data so the data analysis uses quantitative analysis, namely descriptive statistical analysis and inferential statistical analysis. Statistics such as mean, standard deviation, curve are choices in providing descriptive statistical analysis. Testing assumptions using available test models such as the Kolmogorov Smirnov test for normal distribution and the Levene test for variance homogeneity tests.

Anova used is two path anova with interaction. For purposes of analysis, the assumptions that must be met are:

1. Categories in the independent variables in this study are considered permanent meaning the fixed effects model.

2. Error terms are normally distributed with zero average and constant variance

3. Error terms (error terms) do not correlate with each other (free from each other).

The entire calculation process will use a data processing program with Statistical Product and Service Solution (SPSS) software.

The concept of variance analysis is based on the concept of the distribution of $\mathrm{F}$ and can usually be applied to a variety of cases as well as in the analysis of the relationships between the various variables observed. Anova provides F statistics by comparing two elements, namely: 
a. The counter of the F statistic indicates the variability between the average of two or more sample groups (between variant groups)

b. The divisor of the Statistics indicates the variability between observations within each sample group (within the variant group)

Mathematically can be written as follows:

$$
F=\frac{\text { var antar group }}{\text { var di dalam group }}
$$

Through the IBM SPSS program, the statistical value can be directly obtained and the size of the effect size through the partial eta squared value. In one-way ANOVA testing, partial eta squared (PES) is an eta squared because there is only one factor used in the analysis.

Eta-squared is a measure of relationships; provides an overview of how much variance in the Dependent Variable (DV) can be explained by each Independent Variable (IV). (Partial) Eta-squared reflects the percentage of DV variance explained by IV in the sample data.

General rules of thumb given by Cohen and Miles \& Shevlin (2001) for eta-squared written by Watson (2016) are presented:

\begin{tabular}{|c|c|c|c|c|}
\hline Effect Size & Use & Small & Medium & Large \\
\hline$\eta^{2}$ & Anova & 0,01 & 0,06 & 0,14 \\
\hline
\end{tabular}

Then, in addition to the partial eta squared that was raised in the IBM SPSS program, the researcher also determined the size of the effect size by a manual process using a formula developed by Cohen (1998: 284), namely: $f=\sqrt{\frac{\eta^{2}}{1-\eta^{2}}}$ Where: $\eta^{2}$ (etasquared) was obtained from anova test results in research through IBM SPSS 23.0.

\section{RESULTS AND DISCUSSION}

\section{Results}

The first hypothesis statement for this research is: Increased Mathematical Modeling Ability in students who are given learning with PBL based on scafolding is higher than students who are taught with conventional. The results of data processing with Univariate Analysis of Variance are presented. 
Table 3. Results of one way ANOVA analysis on mathematical modeling variables

Levene's Test of Equality of Error Variances ${ }^{a}$

Dependent Variable: Modelling Gain

\begin{tabular}{llll}
\hline $\mathrm{F}$ & df1 & df2 & Sig. \\
\hline 3,215 & 1 & 189 &, 075 \\
\hline Tests the null hypothesis that the error \\
variance of the dependent variable is equal \\
across groups.
\end{tabular}

a. Design: Intercept + Subject Group

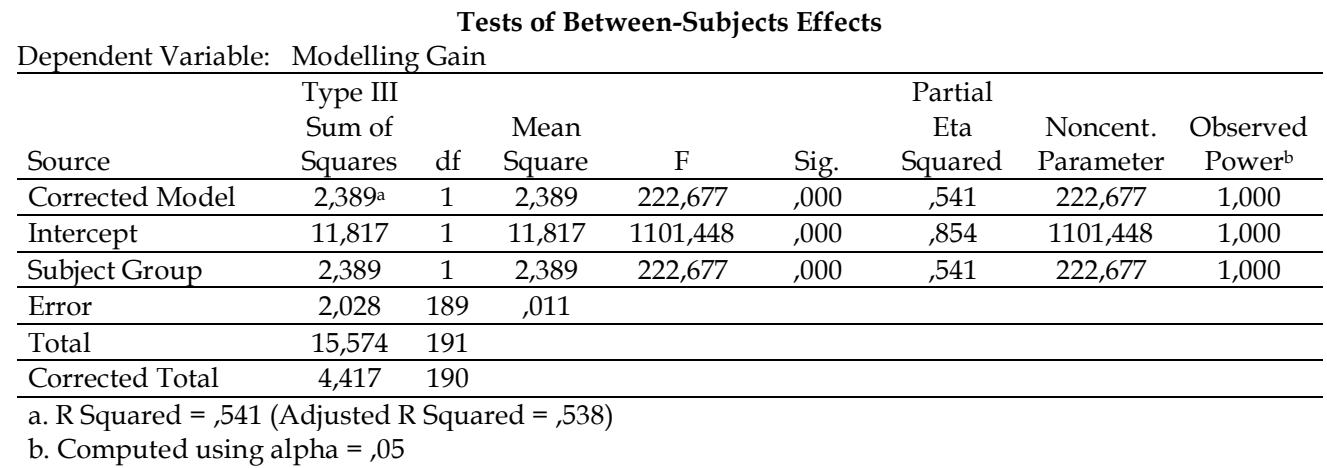

\begin{tabular}{llrrrr}
\multicolumn{7}{l}{ Initial ability * Subject group } \\
Dependent Variable: & Modelling gain & & \\
\hline & & & Std. & \multicolumn{2}{c}{$95 \%$ Confidence Interval } \\
Initial ability & Subject Group & Mean & Error & Lower Bound & Upper Bound \\
\hline low & group experiment &, 301 &, 017 &, 268 &, 333 \\
& group control &, 101 &, 013 &, 075 &, 4128 \\
\hline medium & group experiment &, 382 &, 015 &, 352 &, 180 \\
& group control &, 149 &, 016 &, 118 &, 269 \\
\hline large & group experiment &, 425 &, 022 &, 382 &, 177 \\
& group control &, 223 &, 023 & &, 270 \\
\hline
\end{tabular}

Analysis of the two-way bidirectional results in table 9 above provides an illustration that:

a) The results of the analysis of variance homogeneity through the lavene test show information that the distribution of data on the mathematical modeling ability for the interaction model is homogeneous according to the sig value. $0.079>0.05$ as the recommended value

b) Tests of Between-Subjects Effects results give an F value of 63.133 in Subject Group * KA with sig. of $0,000<0.05$, which indicates that there is an interaction effect, namely the approach applied (PBL based on scafolding and conventional) and the students' initial mathematical abilities, towards increasing their mathematical modeling abilities

c) Effect size on the partial eta squared value in klp_subject * KA gives an indication that the effect of interaction in this model is 0.630 in improving mathematical modeling ability 
d) The adjusted value of $\mathrm{R}$ Square of 0.621 provides an assessment of the effect of giving contributing to the variability of the increase in mathematical modeling variables in the ANOVA model by $62.1 \%$

e) The estimated marginal mean value in the experimental group is higher than in the control group for all initial abilities, ie at high initial abilities $0.301>0.101$; initial ability is $0.382>0.149$; and low initial ability $0.425>0.223$.

Based on the whole set of interpretations it is concluded that the results of this test state that accepting the research hypothesis is that there is an influence of the interaction between the learning approach applied (PBL based on scafolding and conventional) and the students' initial mathematical ability to improve their mathematical modeling abilities.

\section{Discussion}

Scaffolding-based PBL learning process consists of five phases that must be passed including the first phase orienting students to the problem, the teacher explains the learning objectives, logistics required and motivates students to be actively involved in the chosen problem solving activity. The second phase is in the form of organizing students to learn, the problems faced, the teacher can start learning activities by forming groups of students where each group will choose and solve different problems. After students are oriented to a problem and have formed teacher learning groups help students limit and organize learning tasks related to the next teacher and students set specific subtopics, inquiry tasks and schedules. The problem faced until this phase is students who are rather difficult to do the grouping so that it takes a long time to get the children to group in accordance with what was instructed by the teacher.

The third phase is to guide individual and group investigations, the teacher encourages students to collect data and carry out experiments (both mental and actual) until they truly understand the dimensions of the problem situation. After students collect enough data and provide the phenomenon they are investigating, they explain it in the form of a hypothesis or problem solving. At this stage the problem encountered was that assistance in teacher guidance was limited to a few groups because many groups were formed.

The fourth phase is the development and presentation of the work, the teacher helps students plan and prepare appropriate work such as reports and help them to share assignments with their friends. Difficulties faced, especially in elementary school children who have difficulty in equating perceptions between friends so that in preparing a work focused on students who are smarter.

The fifth phase in the form of analyzing and evaluating the problem solving process, the teacher asks students to reconstruct the thoughts and activities that have been carried out during the process of learning activities. This last phase raises time constraints because each student must display the results of problem solving. However, the results of the PBL-based Scaffolding field contributed positively to the ability of mathematical modeling and mathematical communication skills.

The results showed that there was an increase in the ability of mathematical modeling after PBL-based scaffolding compared with students taught by conventional 
methods. With Scaffolding-based PBL students can learn easily through group discussions, students are taught to have responsibilities with their groups. Besides that students are actively involved in the teaching and learning process so students are encouraged to understand the material taught by the teacher and can do mathematical modeling.

The results of this study are in line with the results of Yunin Nunun Nafiah's research, in his research it was concluded that the application of PBL models can improve critical thinking skills and student learning outcomes. It can be seen that applying PBL models can not only improve students' mathematical modeling abilities but can also improve critical thinking skills and student learning outcomes. Then the results of Pitriani's research that said that learning Realistic Mathematics Education (RME) can improve students' mathematical modeling abilities. The equation with research is the dependent variable, namely the ability of mathematical modeling. This can be information that can improve modeling capabilities

\section{CONCLUSION}

Based on the data and discussion, it can be concluded that the improvement of mathematical modeling skills in students who are given learning with PBL based on scaffolding is higher than students who are taught conventionally and there is an interaction effect between applied learning approaches (PBL based on scaffolding and conventional) and students' initial mathematical abilities towards increasing mathematical modeling abilities.

\section{REFERENCES}

[1] Boaler, J. (1999). Participation, knowledge and beliefs: A community perspective on mathematics learning. Educational Studies in Mathematics, 40 (3), 259-281.

[2] Boaler, J. (2002). Exploring the nature of mathematical activity: Using theory, research and 'working hypotheses' to broaden conceptions of mathematics knowing. Educational Studies in Mathematics, 51 (1/2), 3-21.

[3] Clark, R. E., Kirschner, P. A., \& Sweller, J. (2012). Putting students on the path to learning: the case for fully guided instruction. American Educator, 36(1), 6-11

[4] Creswell, J. W. (2012). Research Design Pendekatan Kualitatif, Kuantitatif, dan Mixed. Yogyakarta: Pustaka Pelajar.

[5] Curran, Reggie. (2013) Helping Children Learn In The Primary And Elementary Years Math. A Guide To The Math Common Core State Standards For Parents And Students (Brochure) by. Tennessee State Personnel Development Grant. Tersedia di: www.TNCORE.org

[6] English, L (2003). Mathematical Modelling With Young Learners. In. Susan J. Lamon; Willard A. Parker; Ken Houston (eds). Mathematical Modelling: A Way Of Life. Horwood Publishing Chichester. England

[7] Haylock, D \& Thangata, F. (2007). Key Concepts in Teaching Primary Mathematics. SAGE Publications Ltd. London. http://journal.uniku.ac.id/index.php/JESMath/article/view/282/221. 
[8] Kirschner, P. A., Sweller, J., \& Clark, R. E. (2006). Why minimal guidance during instruction does not work: an analysis of the failure of constructivist, discovery, problem-based, experiential, and inquiry-based teaching. Educational Psychologist, 41,75-86. http://dx.doi.org/10.1207/s15326985sep4102_1.

[9] Lesh, R., Cramer, K., Doerr, H. M., Post, T., \& Zawojewski, J. (2003). Model development sequences. In H. M. Doerr \& R. Lesh (Eds.), Beyond constructivism: A models $\mathcal{E}$ modeling perspective on mathematics problem solving, learning $\mathcal{E}$ teaching (pp. 35-58). Hillsdale, NJ: Lawrence Erlbaum Associates, Inc.

[10] Lesh, R., Doerr, H. M., Carmona, G., \& Hjalmarson, M. (2003). Beyond constructivism. Mathematical Thinking and Learning, 5(2), 211-234.

[11] Maas, K., (2006.) What are competencies, University of Education Freiburg: ZDM .38(2), 113-141

[12] Mousoulides, N.; Pittalis, M. \& Christou, C. (2006). Improving Mathematical Knowledge Through Modeling In Elementary Schools. In Novotná, J., Moraová, H., Krátká, M. \& Stehlíková, N. (Eds.). Proceedings 30 ${ }^{\text {th }}$ Conference of the International Group for the Psychology of Mathematics Education, Vol. 4, pp. 201-208. Prague: PME. 4 - 201

[13] Mousoulides, N.G. (2009). Mathematical Modeling for Elementary and Secondary School Teachers. Tersedia di : www.lema-roject.org/web.. ./web/dvd... / mousoulides_chapter_lema.doc

[14] National Council of Teacher of Mathematics. (2000). Principles and standards for school mathematics. Reston, VA: The National Council of Teachers of Mathematics, Inc.

[15] OECD. (2014). PISA 2012 Results in Focus What 15-year-olds know and what they can do with what they know. Tersedia di : http://www.oecd.org /pisa/keyfindings/pisa-2012-results-overview.pdf

[16] Papageorgiou, G. (2009). The Effect og Mathematical modeling on student' affect. Thesis. AMSTEL Institute Universiteit Vans Amsterdam, Netherlands.

[17] Pitriani, P. (2006). Ability to Model Mathematics in Realistic Mathematics Education (RME), Jurnal Edukasi E Sains Matematika. 2, 76.

[18] Randall I. C. \& Carmel, CA. (2005) Big Ideas and Understandings as the Foundation for Elementary and Middle School Mathematics. Journal of Mathematics Education Leadership, 7(3), 9-23.

[19] Riyanto, Y. (2009). New Learning Paradigm. Jakarta: Kencana Prenada.

[20] Schifter, D., Russell, S.J., \& Bastable, V. (1999) Teaching to the Big Ideas. In The Diagnostic Teacher: Constructing New Approaches to Professional Development, edited by Mildred Z. Solomon. New York, New York: Teachers College Press. 22-47.

[21] Sierens, E., Soenens, B., Vansteenkiste, M., Goossens, L., \& Dochy, F. (2006). The authoritative teaching style: a model for the study of teaching styles. Pedagogische Studien, 83, 419-431. 
[22] Sweller, J., Kirschner, P. A., \& Clark, R. E. (2007). Why minimally guided teaching techniques do not work: a reply to commentaries. Educational Psychologist, 42, 115-121. http://dx.doi.org/10.1080/00461520701263426.

[23] Verschaffel, L. (2002). Taking the modelling perspective seriously at the elementary school level: promises and pitfalls. In A. Cockburn \& E. Nardi (Eds.), Proceedings of 26th Annual Meeting of the International Group for the Psychology of Mathematics Education, 1, 64-80. Norwich: University of East Anglia.

[24] Nafiah, Y. N. (2014). Application of Problem Based Learning (PBL) Learning Model to Improve Critical Thinking Skills and Student Learning Outcomes". Jurnal Pendidikan
https://journal.uny.ac.id/index.php/jpv/article/view/2540.

141.

http://jurnalnasional.ump/index.php/dinamika 